\title{
A sex difference in the leucocyte count
}

\author{
R. N. ALlAN AND M. K. ALEXANDER \\ From South Warwickshire Hospital Group Pathological Laboratory, Warwick
}

SYNOPSIS In a study of a group of 325 blood donors between the ages of 18 and 65 years, the total leucocyte and polymorph counts of the females aged 50 to 65 years were found to be significantly lower than those of the corresponding group of male donors. In the whole series of female donors, there were significantly lower total leucocyte and lymphocyte counts with increasing age and a less significant $(P \bumpeq 0 \cdot 1)$ fall in the polymorph count. No age variation in the male counts was found.

Analysis of large numbers of leucocyte counts performed on hospital patients has confirmed the sex difference in the total leucocyte count found in the blood donors.

The factors responsible for the differences are discussed.

The advent of modern data processing techniques in the clinical laboratory has made practical the analysis of large quantities of data routinely acquired (Hipwell, 1967). A preliminary examination of the leucocyte counts of hospital patients suggested the need for a re-examination of the total and differential leucocyte count with respect to a possible sex difference and the investigation was therefore extended to a group of healthy blood donors and a large group of hospital patients.

\section{MATERIAL}

Three hundred and twenty-five healthy blood donors between the ages of 18 to 65 years were investigated. Two hundred consecutive donors were sampled initially, and subsequently to obtain significant numbers throughout the age range only donors aged 30 years and over. For statistical analysis, the donors were divided into four age groups (Table I). Potential donors who failed the haemoglobin screening test or who were rejected on health grounds were not included.

Results from hospital patients were also analysed. The patients are drawn from a hospital with general medicine, general surgery, orthopaedic, and ENT departments. There are no obstetric beds.

It is the practice of this laboratory to estimate total white blood cell counts on all specimens received. All results, with complete identification of each patient in respect of age and sex, within the range haemoglobin 2 to $21 \mathrm{~g} / 100 \mathrm{ml}$ and WBC 2 to $21,000 / \mathrm{c} \mathrm{mm}$, were included. Three consecutive months (March, April, May 1967) were analysed. A total of 911 men and 864 women fulfilled these criteria. The age and sex composition of the group is shown in Table I.

Received for publication 20 February, 1968.
TABLE I

AGE AND SEX DISTRIBUTION OF SAMPLE

\begin{tabular}{lrrrrr} 
Age in years & $18-29$ & $30-39$ & $40-49$ & $50-65$ & Totals \\
\hline $\begin{array}{l}\text { Blood Donors } \\
\quad \text { Male }\end{array}$ & 41 & 52 & 52 & 33 & 178 \\
$\quad \begin{array}{l}\text { Female } \\
\text { Total }\end{array}$ & 43 & 22 & 48 & 34 & 147 \\
$\begin{array}{l}\text { Hospital Patients } \\
\text { Male }\end{array}$ & 84 & 74 & 100 & 67 & 325 \\
$\quad$ Female & 130 & 132 & 214 & 435 & 911 \\
Total & 217 & 152 & 186 & 309 & 864 \\
& 347 & 284 & 400 & 744 & 1,775
\end{tabular}

METHODS

Samples of venous blood were drawn from blood donors at the end of donation with the donor supine and at rest. As there is a tendency for the white count to rise in the late afternoon (de Gruchy, 1964) and there was a male preponderance at the later sessions, samples were only drawn during the morning and early afternoon. The age and sex distribution of the donors at these times is shown in Table II.

TABLE II

TIME OF SAMPLING BLOOD DONORS

\begin{tabular}{clllll} 
& \multicolumn{2}{l}{$\begin{array}{l}\text { Morning } \\
(9.30-12.30\end{array}$} & \multicolumn{2}{l}{$\begin{array}{l}\text { Afternoon } \\
(1.30-3.15)\end{array}$} \\
\cline { 2 - 6 } Age in Years & $M$ & $F$ & $M$ & $F$ \\
\hline $18-29$ & 12 & 12 & 29 & 31 \\
$30-39$ & 17 & 11 & 35 & 11 \\
$40-49$ & 18 & 19 & 34 & 29 \\
$50-65$ & 14 & 16 & 19 & 18
\end{tabular}

Blood films were made immediately: films were stained and haemoglobin and total white counts estimated the same day. 
After thorough mixing, a $10 \mathrm{ml} 1 / 250$ dilution of each sample was prepared. Total white cell counts were measured with a Coulter counter. The remainder of this specimen was used for estimating haemoglobin values by an oxyhaemoglobin method. One hundred cells were examined on each film for the differential white cell count.

The sex of the donors was recorded separately so that this information was not available when the estimations were carried out.

All results were entered on punch cards and used as input to an IBM 1440 computer programmed to produce histograms of the haemoglobin and total and differential white count distributions for males and females as well as carry out the statistical analyses.

\section{STATISTICAL METHOD}

Techniques employed included determination of correlation coefficients and analysis of variance. As the latter is valid only for parameters of normal distribution and examination of the histograms having shown that the results were not normally distributed, logarithmic values of the total and differential white cell counts, which gave normal distributions, were used in the analysis.

Analysis of variance was employed to determine whether there was a significant sex difference in the total and differential white cell count in the different age groups.

The coefficient or correlation between the haemoglobin value and total white cell count in the two sexes at different ages was calculated to determine whether the changes in the normal white count were related to changing haemoglobin levels. The coefficient of correlation between age and total and differential white counts in both sexes was also calculated.
RESULTS

BLOOD DONORS No significant sex difference in the total white cell count was found under 50 years of age. In the age group 50 to 65 years the total females white count is significantly lower than the malep (Table III).

Analysis of the differential white count results showed that this was due to a significantly lowep polymorph count in the female in this age group (Table III).

With increasing age in women there was के significant fall in the total white cell count due to falling lymphocyte count and a less marked fall in the polymorph count. In men there was no significant variation of either the total or differentiale counts with age (Table IV).

\section{TABLE IV}

COEFFICIENT OF CORRELATION BETWEEN AGE AND WHITE CELL COUNT IN BLOOD DONORS

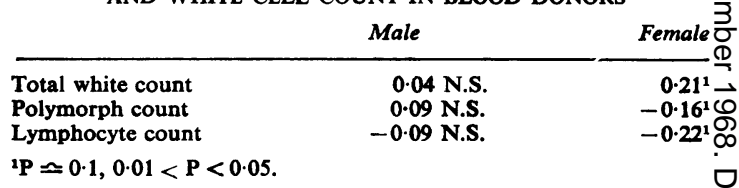

There was significant correlation in women aged 50 to 65 years between the haemoglobin values anc both the total and polymorph counts (Table VE although the mean haemoglobin of this group did? not differ significantly from the overall female mean (Table VI).

TABLE III

MEAN WBC/C MM BY AGE AND SEX IN BLOOD DONORS

\begin{tabular}{|c|c|c|c|c|c|c|c|c|c|}
\hline \multirow{2}{*}{$\begin{array}{l}\text { Age } \\
(y r)\end{array}$} & \multicolumn{3}{|c|}{ Total WBC } & \multicolumn{3}{|c|}{ Polymorph Count } & \multicolumn{3}{|c|}{ Lymphocyte Count } \\
\hline & Male & Female & $\begin{array}{l}\text { Significance } \\
\text { of Difference }\end{array}$ & Male & Female & $\begin{array}{l}\text { Significance } \\
\text { of Difference }\end{array}$ & Male & Female & $\begin{array}{l}\text { Significance } \\
\text { of Difference }\end{array}$ \\
\hline $\begin{array}{l}18-29 \\
30-39 \\
40-49 \\
50-65\end{array}$ & $\begin{array}{l}5,200 \\
5,500 \\
5,300 \\
5,600\end{array}$ & $\begin{array}{l}5,700 \\
5,100 \\
5,200 \\
4,800\end{array}$ & $\begin{array}{l}\text { N.S. } \\
\text { N.S. } \\
\text { N.S. } \\
\text { i }\end{array}$ & $\begin{array}{l}2,900 \\
3,100 \\
3,100 \\
3,200\end{array}$ & $\begin{array}{l}3,300 \\
2,900 \\
3,100 \\
2,700\end{array}$ & $\begin{array}{l}\text { N.S. } \\
\text { N.S. } \\
\text { N.S. } \\
1\end{array}$ & $\begin{array}{l}2,000 \\
1,900 \\
1,800 \\
1,900\end{array}$ & $\begin{array}{l}2,100 \\
2,000 \\
1,800 \\
1,700\end{array}$ & $\begin{array}{l}\text { N.S. } \\
\text { N.S. } \\
\text { N.S. } \\
\text { N.S. }\end{array}$ \\
\hline
\end{tabular}

TABLE V

COEFFICIENT OF CORRELATION BETWEEN HAEMOGLOBIN AND WHITE COUNT IN BLOOD DONORS

\begin{tabular}{|c|c|c|c|c|c|c|}
\hline \multirow{2}{*}{$\begin{array}{l}\text { Age } \\
(y r)\end{array}$} & \multicolumn{2}{|c|}{ Total $W B C$} & \multicolumn{2}{|c|}{ Polymorph Count } & \multicolumn{2}{|c|}{ Lymphocyte Count } \\
\hline & Male & Female & Male & Female & Male & Femal \\
\hline $\begin{array}{l}18-29 \\
30-39 \\
40-49 \\
50-65\end{array}$ & $\begin{array}{l}0.35^{1} \\
0.07 \\
0.10 \\
0.25\end{array}$ & $\begin{array}{l}0.22 \\
0.05 \\
0 \cdot 11 \\
0.41^{1}\end{array}$ & $\begin{array}{l}0.27 \\
0.13 \\
0.06 \\
0.14\end{array}$ & $\begin{array}{l}0.22 \\
0.08 \\
0.09 \\
0.40^{1}\end{array}$ & $\begin{array}{l}0.39 \\
0.15 \\
0.09 \\
0.18\end{array}$ & $\begin{array}{l}0.18 \\
0.11 \\
0.02 \\
0.26\end{array}$ \\
\hline \multicolumn{7}{|c|}{${ }^{1} 0.01<P<0.05$, other results $P>0.1$} \\
\hline
\end{tabular}


HOSPITAL GROUP In this group the sex difference in the total white count was significant between the ages of 30 and 49 years and very highly significant between 50 and 65 years (Table VII). There was a highly significant correlation between the haemoglobin and total white count (Table VIII) in females aged 30 to 39 years and significant correlation in the age groups 40 to 49 years and 50 to 65 years, although the mean haemoglobins of the different age groups did not differ significantly from each other (Table VI).

\section{TABLE VI}

VARIATION IN HAEMOGLOBIN WITH AGE AND SEX (IN G/100 ML)

\begin{tabular}{|c|c|c|c|c|}
\hline \multirow{2}{*}{$\begin{array}{c}\text { Age } \\
(y r)\end{array}$} & \multicolumn{2}{|c|}{ Blood Donors } & \multicolumn{2}{|c|}{ Hospital Patients } \\
\hline & Male & Female & Male & Female \\
\hline $\begin{array}{r}18-29 \\
30-39 \\
40-49 \\
50-65\end{array}$ & $\begin{array}{l}14.6 \\
14.9 \\
14.6 \\
14.5\end{array}$ & $\begin{array}{l}11.8 \\
12.4 \\
12.9 \\
13.1\end{array}$ & $\begin{array}{l}13.7 \\
13.9 \\
13 \cdot 7 \\
13.2\end{array}$ & $\begin{array}{l}12 \cdot 4 \\
12 \cdot 3 \\
12 \cdot 3 \\
12 \cdot 2\end{array}$ \\
\hline
\end{tabular}

TABLE VII

MEAN TOTAL WBC/C MM BY AGE AND SEX IN

\begin{tabular}{cccc}
$\begin{array}{c}\text { Age } \\
(y r)\end{array}$ & Male & Female & $\begin{array}{l}\text { Significance of } \\
\text { Difference }\end{array}$ \\
\hline $18-29$ & 7,100 & 7,300 & N.S. \\
$30-39$ & 6,600 & 5,900 & $0.01>P<0.05$ \\
$40-49$ & 7,000 & 6,300 & $0.01>P<0.05$ \\
$50-65$ & 7,200 & 6,100 & $0.0001>P<0.001$
\end{tabular}

TABLE VIII

COEFFICIENT OF CORRELATION BETWEEN HAEMOGLOBIN AND TOTAL WHITE COUNT IN HOSPITAL PATIENTS

\begin{tabular}{lcc}
$\begin{array}{l}\text { Age } \\
(y r)\end{array}$ & Male & Female \\
\hline $18-29$ & & \\
$30-39$ & 0.16 & 0.00 \\
$40-49$ & 0.10 & $0.41+$ \\
$50-65$ & 0.01 & $0.22+$ \\
$10.01<\mathrm{P}<0.05,+0.0001<\mathrm{P}<0.001$. & $0.23^{1}$
\end{tabular}

\section{DISCUSSION}

METHODS Blood donors were chosen for the investigation primarily to obtain a sample covering a wide age group of presumably healthy people who have passed a haemoglobin screening test and from whom samples can be obtained in large numbers under standard conditions. Although sampling was performed at the end of donation, there is a delay of several hours before haemodilution or the reactive leucocytosis of haemorrhage occurs (de Gruchy, 1964) so that no effect on the counts would be anticipated from this cause. Blood samples were collected at several centres and one of us was present at each session to ensure that consecutive samples were being obtained. Haemoglobin estimations and total white counts were all carried out by the same person.

In the hospital sample grossly abnormal white counts $(>21,000 / \mathrm{c} \mathrm{mm})$ were excluded but all other results retained to avoid material alteration of the white count distribution by truncation.

RESULTS As far as we are aware the only evidence previously provided for a sex difference in the normal leucocyte count is that of Previtera, Venezia, and Vignale (1966), who from a study of 735 men and 939 women aged 1 to 25 years, found in men between 10 and 20 years a lower neutrophil count and between 5 and 25 years a higher lymphocyte count than in women. These results of Previtera et al (1966) are at variance with those of Osgood (1935), Geller and Sukhanova (1964), and the present findings.

In an investigation of the normal haematological standards of 500 healthy individuals Osgood (1935) concluded that there is no sex difference in total and differential leucocyte counts at any age. However, the majority of his subjects were under 30 years of age. We have confirmed the conclusions of Osgood, Brownlee, Osgood, Ellis, and Cohen (1939) where no significant sex difference was found in the leucocyte count of a group aged 19 to 30 years.

In a study of 439 healthy Russians, Geller and Sukhanova (1964) found no age or sex differences in the leucocyte count, but all his subjects were under 50 years of age.

Other sources of variation in the leucocyte count are well recognized and include a diurnal variation (Sabin, Cunningham, Doan, and Kindwall, 1925) and a cyclic variation in men with a cycle length of 14 to 23 days (Morley, 1966). Evidence for a seasonal variation is disputed, that described by EngelbrethHolm and Videbaek (1948) being unconfirmed in an extensive study of 15,000 individuals by Riabov and Talantova (1963).

The reasons for the sex differences found in the present investigations cannot at present be satisfactorily explained. Among the factors calling for consideration are the possible effects of hormonal sex differences. Although it is known that administration of ACTH or cortisone is followed by a rise in the neutrophil and a fall in the lymphocyte count (Code, Mitchell, and Kennedy, 1954), there is no evidence that the ratio of the plasma cortisol levels of the sexes as reflected by excretion of 17-ketosteroids and 17-ketogenic steroids is altered with increasing age (Borth, Linder, and Riondel, 1957). Moreover this pattern of change in cell count does not conform to that found in the blood donors. 
The presence of a significant correlation between haemoglobin level and polymorph counts in several age groups of female blood donors and hospital patients suggests the possible implication of a nutritional or metabolic factor influencing both parameters. Although a fall with advancing age has usually been found, the majority of studies of serum $B_{12}$ levels in which the results have been considered with respect to sex (Gaffney, Horonick, Okuda, Meier, Chow, and Shock, 1957; Cape and Shinton, 1961; Matthews, 1962; Kilpatrick and Withey, 1965; Nielsen, 1965) have failed to show any significant difference, the sole exceptions being that of Killander (1957) who demonstrated a lower mean level in females at all ages. Similarly, Read, Gough, Pardoe, and Nicholas (1965) and Girdwood, Thomson, and Williamson (1967) failed to demonstrate any sex difference in serum folate values.

That the mean serum iron declines with age in both sexes and is lower at all ages in women than men was established among others by Pirrie (1952). The possible relevance of this finding to the results of the study is at present uncertain.

We should like to thank Dr W. G. W. Bird of the Birmingham Regional Blood Transfusion Service for his cooperation in obtaining blood samples, and the
Computer Centre, Medical School, Birmingham, for computer facilities.

R.N.A. was in receipt of a Sheldon clinical researcho fellowship from the Birmingham Regional Hospitalo Board.

\section{REFERENCES}

Borth, R., Linder, A., and Riondel, A. (1957). Acta endocr. (Kbh.), 25 33.

Cape, R. D. T., and Shinton, N. K. (1961). Geront. clin. (Basel), 3, 163

Code, C. F., Mitchell, R. G., and Kennedy, J. C. (1954). Mayo Clin.O Proc., 29, 200.

de Gruchy, G. C. (1964). Clinical Haematology, in Medical Practice, $\overrightarrow{ }$

2nd ed., p. 327. Blackwell, Oxford.

Engelbreth-Holm, J., and Videbaek, A. (1948). Blood, 3, 612

Gaffney, G. W., Horonick, A., Okuda, L., Meier, P., Chow, B. F., and Shock, N. W. (1957). J. Geront., 12, 32.

Geller, L. I., and Sukhanova, V. A. (1964). Probl. Gemat., 9, 25.

Girdwood, R. H., Thomson, A. D., and Williamson, J. (1967). Brit. med. J., $2,670$.

Hipwell, J. C. (1967). Data Processing Vol. 9, No. 2, p. 69.

Killander, A. (1957). Acta Paediat. (Uppsala), 46, 585.

Kilpatrick, G. S., and Withey, J. L. (1965). Scand. J. Haemat., 2, 22.

Matthews, D. M. (1962). Clin. Sci., 22, 101.

Morley, A. A. (1966), Lancet, 2, 1220.

Nielsen, B. (1965). Acta neurol. scand., 41, 513.

Osgood, E. E. (1935). Arch. intern. Med., 56, 849. Brownlee, I. E., Osgood, M. W., Ellis, D. M., and Cohen, W (1939). Ibid., 64, 105.

Pirrie, R. (1952). J. clin. Path., 5, 10.

Previtera, A., Venezia, A., and Vignale, A. M. (1966). Arch. ital. Pediat., 24, 102.

Read, A. E., Gough, K. R., Pardoe, J. L., and Nicholas, A. (1965). Brit. med.J., 2, 843.

Riabov, S. I., and Talantova, I. V. (1963). Probl. Gemat., 8, 26.

Sabin, F. R., Cunningham, R. S., Doan, C. A., and Kindwall, J. A.O (1925). Bull. Johns Hopk. Hosp., 37, 14. 